Since its comparatively recent introduction into Egypt the pink boll-worm, Pectinophora (Gelechia) gossypiella, has so rapidly increased that it has for some years been the chief insect pest of cotton. Much scientific work is being done on its life-history and on its effect on the cotton crop with the view of attacking the pest in the most effective manner, as it may now be classed on a par with the Phylloxera of vines for destructiveness. Field experiments indicate that the effect of Gelechia attack may be rendered less harmful by reducing the water-supply in July and stopping it altogether after the first week in August, as by this means the yield of cotton is increased and the crop ripens earlier.

During the last sixteen years the farmers of Cyprus have exhibited an enlightened and receptive attitude towards modern agricultural methods, with the result that considerable improvements have taken place in the agriculture of the island. These changes are set forth by Mr. W. Bevan in the Bulletin of the Imperial Institute (vol. xvii., No. 3, pp. 302-58), and the resources and possibilities of the island are hriefly summarised. About $1,200,000$ acres are under cul. tivation, but another 770,000 acres are either under forest or could be cultivated. The average rainfall is about 20 in. per annum, and the climate, especially in the plains, shows considerable extremes of temperature. Agriculture is the main industry, but methods and appliances are behind the times, though improve. ments are being effected through the activities of the Agricultural Department. Irrigation is essential, and if a satisfactory solution of the water problem could be reached, large fertile areas which now have to remain fallow could be brought under cultivation for growing cotton and other similar crops and for extending vegetable and fruit culture. A consider. able amount of stock-raising is carried on, sheeprearing being an important industry. Cheese and butter are made from sheep's and goat's milk, largely for home consumption, though some is exported to Egypt. Poultry-farming could be made very profitable, as the climate and food-supply are suitable, but ignorance of proper management at present hinders the industry from prospering.

The chief cereals grown are wheat, barley, and oats, though maize and rye have been introduced during the last few years. Fruit-growing is of much importance, and the export trade in this respect is considerable, some amount of wine and spirits also being produced and sent abroad. Market-gardening is receiving much attention, as there is a good demand in Egypt for fresh vegetables which are raised round the "ports" of Cyprus.

\section{Heredity and Eugenics.}

DR. R. RUGGLES GATES contributes to the latest number of the Eugenics Review a valuable essay on heredity and eugenics. "Probably in no other species of animal or plant does the number of differences between individuals approach the number to be observed in man." "It has now become a commonplace of observation that the differences between organisms, as well as their resemblances, are often inherited." Heredity includes both the entailment of parental variations and the possibility of new variations. A very interesting survey is taken of the inheritance of both physical and mental characters in man. Eugenic action should include, if only there were sufficient knowledge, ( $r$ ) positive selection for desirable qualities, which are frequently dominant; (2) negative selection against undesirable recessive qualities which appear in collateral or ancestral lines, No. 2660 , voL. Io6] and may therefore be carried in the family germ plasm; (3) isolation of individuals having undesirable dominant qualities; and (4) an effort to foster matings between individuals showing the same desirable recessive quality. Another interesting feature of Dr. Ruggles Gates's paper is the discussion of the question whether there are any details of structure so small or of such a nature as to be beyond the reach of hereditary entailment. Some good examples are given of the continuance of very minute structural idiosyncrasies. As regards the inbreeding and outbreeding of human races, the author concludes that intermixture of unrelated races is from every point of view undesirable. "The more advanced race is diluted and degraded by such intermixture." "The blend is only a blend when considered en masse." On the other hand, interbreeding of related races or strains gives increased vigour.

\section{University and Educational Intelligence.}

AberdeEn.-The Lord Rector, Lord Cowdray, will deliver his address in. the Mitchell Hall on October 23.

Dr. J. B. Orr, director of the Rowett Research Institute, has been appointed research lecturer in the physiology of nutrition for the ensuing academical year, and Mr. R. H. A. Plimmer, chief biochemist, re-appointed research lecturer in applied biochemistry.

Cambridge.-Mr. S. M. Wadham, Christ's College, has been appointed senior demonstrator in botany, and Mr. R. E. Holthum, St. John's College, junior demonstrator.

LONDON.-In response to a request made by many of those who attended Dr. Jeffery's public lecture on Einstein's theory of relativity, a course of eight lectures on the same subject by Dr. Jeffery has been arranged at University College. The course will begin on Monday, October 25, at 6 p.m.

A course of ten public lectures on "The Develop. ment of Philosophy from Descartes to Leibriz" is being given at King's College by Prof. H. Wildon Carr on Tuesdays at 5.30 p.m. The course com. menced on October 12 .

OXFORD.-The new academical year has begun with a very large number of fresh entries. The colleges are almost inconveniently full, and most of the scientific departments are overcrowded. The activities of the teaching staff of both University and colleges are being taxed to the utmost. A contributing cause of the present pressure upon the resources of accommodation and teaching is the influx of women students, who are now to be seen in the academic costume lately devised for their use.

On October I4 a new departure was taken by the admission of nearly sixty women to degrees; these included the conferring of the degree of M.A. by decree on the Principals of the women's colleges and halls and of the Society of Oxford Home-Students.

A letter has been addressed by some members of the University to the professors of the arts and sciences and to members of the universities and learned societies in Germany and Austria, expressing a "desire to dispel the embitterment of animosities that under the impulse of loyal patriotism may have passed between us," and suggesting that a reconciliation may surely be looked for in the fields of arts and learning.

Mr. J. R. C. Gordon has been appointed protessot of materia medica and therapeutics at the Anderson College of Medicine, Glasgow. 
The new session of the Aristotelian Society will be inaugurated on Monday, November 8 , at 8 o'clock, when the president, Dean Inge, will give an address on "Is the Time Series Reversible?" The meeting will be held in the Conference Hall of the University of London Club, 2I Gower Street, W.C.x.

FREE public lectures on physic will be delivered by Sir Robert Armstrong-Jones at Gresham College, Basinghall Street, E.C.2, at 6 p.m., on November 8, IO, II, and I2. The subjects of the lectures will be "The Air We Breathe," "The Houses We Live In," "The Clothes We Wear," and "The Food We Eat."

THE British Medical Journal for October 16 states that the University of Heidelberg has received 500,000 marlis from Herr F. Behringer, of Bielenfeld, for the erection of an institute for the study of the chemical constitution of albumin. Until the institute is completed the researches will be carried on in the physiological institute under the direction of Prof. Kossel.

WE learn from School Life for August I5 last that Mr. August Heckscher, of New York City, has given 500,000 dollars to Cornell University to maintain professorships of research and to provide facilities for scientific work. The persons selected for such positions will be relieved of routine teaching and administrative details in order that they may be free to devote, themselves to scientific investigation and to the training of future investigators.

ON October 18 the report of the Higher Education Sub-Committee on London University was adopted at a special meeting of the Education Committee of the London County Council. Mr. H. C. Gooch said that, having obtained an assurance from the President of the Board of Education that acceptance of the Bloomsbury site for the headquarters of the University would not close the door against grants from Treasury sources towards the building and equipment of the new premises, the Sub-Committee felt justified in recommending the Education Committee to ask the Council to make a conditional building grant. He moved: "That, subject to satisfactory arrangements being made between the Government and the Council of King's College for the reinstatement of King's College on the proposed Bloomsbury site, and in the event of the University of London accepting the site in Bloomsbury referred to in Mr. H. A. L. Fisher's letter dated April 7, I920, and provided that adequate grants are made by the Government for the erection of administrative buildings on the new site, the Council is prepared to consider an application for a building grant for this purpose subject to the condition that the Council's contribution shall not exceed one-third of the contribution made by the Government in respect of expenditure not exceeding $x, 000,000 l$, and that the Council be recommended accordingly." The resolution was adopted by eighteen votes against five.

The Y.M.C.A. Universities Committee, of which Dr. D. H. S. Cranage is chairman and the Rev. Basil A. Yeaxlee secretary, has issued an admirable educational handbook for the guidance of secretaries and for providing suggestions for the building up of local educational programmes for the various branches of the Y.M.C.A. according to their respective needs. There has been established with this object an education department at the headquarters of the association, I3 Russell Square, W.C.I, from which further advice and guidance can be obtained. It is proposed to establish throughout the kingdom divisional areas connected with the local branches NO. 2660 , VOL. IO6] of the Y.M.C.A., each with its educational com mittee representative not only of the members, but also of the local educational activities, whether official or voluntary. The movement is chiefly concerned with the supply of adult education, the emphasis upon which should lie largely with non-vocational subjects such as religion, history, sociology, science, literature, the arts, and physical education, the technical and vocational studies being offered only when other educational agencies fail to provide them. It is earnestly advocated that one of the greatest needs of our country to-day is a democracy with the power to think and to form judgments, people who have the country's welfare at heart and are prepared to take their place as citizens, understanding clearly the implications and duties of citizenship. Having this purpose in view, the National Council has asked the universities and other bodies co-operating with the association in its war-time educational work to continue to send representatives to form the Y.M.C.A. Universities Committee, and the response has been cordial and complete, a body being formed comprised of eighty-five members representative of all the universities and the university colleges of Great Britain and other voluntary agencies. Well-defined lecture and tutorial courses upon a variety of subjects are arranged, including philosophy, history and geography, literature, art, religion and morals, economics, music and the drama, and suggestions for correspondence groups, for the formation of libraries, and for summer and week-end schools are offered.

From the Pioneer Mail for August I3 last we learn that an extraordinary meeting of the Senate of Allahabad University was held on August $\eta$, at which Sir Harcourt Butler, Chancellor of the University, presided. In opening the debate, the Chancellor said that the policy in the United Provinces for higher education was the development of a number of universities of the unitary, residential, and teaching type. The first step in this direction was the estab. lishment of an institution on these lines at Lucknow, and a Bill had been prepared and published which aimed at putting into force the recommendations of the Lucknow University Conference. The second step was that the line between university and school teaching should in future be drawn at the intermediate stage. This involved the re-organisation of secondary education. To this end it was proposed to establish a Board which would supersede the existing School-leaving Certificate Board, and be entrusted with the task of providing the preparation for university work now given in the intermediate classes of the college, and of developing a system of high secondary education. The third step to be accomplished was the re-organisation of Allahabad University. It should be divided into two parts, one, internal, being a self-contained unitary, residential, and teaching university, and the other, external, consisting of affiliated outlying colleges. In conclusion, it was pointed out that primary, secondary, and technical education would not be in any way retarded by lack of finances should the schemes for university reform be adopted. A discussion followed, and the Senate passed a resolution, moved by Dr. Sapru, approving the general scheme for establishing a university at Lucknow, but reserving its opinion as to details. Motions were also passed bv which the draft Bill for the establishment of a Board for High School and Intermediate Education, and the renort of the committee on the re-organisation of Allahabad University, should be referred to a Select Committee.

IN Bulletin No. 50, I9I9, of the United States Bureau of Education an account is given of the condition of science teaching in the scheols of 
Memphis, Tennessee. The bulletin is divided into four sections, dealing with the elementary schools, the central high school, the vocational high school, and the high school for coloured children. In the elementary grades no science or Nature-study enters into the curriculum. At the central high school instruction is divided into eight groups, according to the principal subject taken: Latin, history, science, modern languages, commerce, technical training, home economics, and a course in which any subjects may be taken. In five of these groups no science studies are essential; in one, one science subject is necessary, in another two are required, and in the remaining one five are compulsory. However, in six of the groups either four or five sciences are voluntary, and another offers three "elective" sciences, but in the commercial group no science studies are undertaken. 'The number of students actually taking scientific subjects amounts to only 28.7 per cent. of the total number of pupils on the books, and measures are suggested for ensuring that a greater number obtain some training in science. Part of the scheme suggested is that general science should be taught in the upper classes of the elementary schools. The number of teachers employed in teaching science, and in many cases their qualifications, appear to be quite inadequate to the task before them. At the vocational high school shop-work is prominent, but it is surprising to note that there are no laboratories equipped for work in science, and no teachers apparently who are competent to teach such subjects. In the high school for coloured children the condition of scientific studies is even worse; it is impossible to do anvthing but textbook and recitation work, and even this is done only with great difficulty on account of the constant overcrowding of the room. The whole school is reported as unclean and insanitary and in a pitiable condition.

A COPy of the regulations and syllabus of the British School of Malting and Brewing for the year 1920-2I has been received. The school is a department of Birmingham University, and deals with all branches of applied biochemistry, especially as applied to fermentation industries, to agriculture, and to sanitation. Four courses of instruction are provided-a degree course, a diploma course, a part-time series of lectures for brewers and maltsters leading to a certificate, and special short courses on malting and brewing. The lectures for the degree are recommended to students desirous of qualifying as chemists or bacteriologists in industries in which biochemistry plays an important part. A fourth year's work in the department of brewing qualifies a sraduate for the diploma in that science. The diploma course is intended for students leaving school who desire training in the principles of malting, brewing, and other fermentation industries. The first two years are devoted to general scientific training as a preparation for the technical work of the third year, which consists largely of acquiring a practical knowledge of brewing and of the methods used by brewers in the judgment and valuation of barlev, malt and other requisites of the trade. The part-time course for brewers and maltsters is open to all. but to qualify for the University certificate the candidate must have had two vears' practical experience in brewing or malting. The ground covered is similar to that dealt with in prenaration for the diploma, but the laboratory work does not so so far into the scientific side of the operations. The short courses provided are intended for those who find themselves unable to attend any of the above classes: such students share all advantages equally with diploma students. A No. 2660, VOL. IO6] time-table and syllabus of each course are given in the booklet. It is interesting to note that the director of the school, Prof. A. K. Ling, has been given wide powers for aiding competent research workers concerned with fermentation industries by finding acconmodation in his laboratories and in other ways. Applications for such assistance should be made dircet to the director of the school.

\section{Societies and Academies.}

\section{MaNCHESTER.}

Literarv and Philosophical Society, October 5--Sir Henry A. Miers, president, in the chair.-Dr. A. E. Oxley: Rerent researches in magnetism. After dealing briefly with the nature of ferro-magnetism, paramagnetism, and diamagnetism, the author considered the characteristic variations of these properties over a range of temperature varying from that of liquid air to $300^{\circ} \mathrm{C}$. Practically all substances show a change of magnetic property when crystallisation takes place, and in the case of certain diamagnetic substances definite hysteresis loops with respect to temperature have been obtained. These loops are similar to those shown by nicliel-steels which are ferromagnetic. 'The experimental results were interpreted in terms of the electron theory of magnetism, and finally extended, through Tyndall's work on the deportment of crystals in a magnetic field, to interpret the nature of crystal structure and the spatial distribution of electrons within the atom. The atomic configuration so deduced is similar to that of the cubical atom developed by Levis and Langmuir, and distinct from that of the Bohr theory, which fails to account for the magnetic properties. It is considered, however, that these theories may be brought into line in the near future by a due recognition of the possible differences between radiating and nonradiating matter.

\section{PARIS.}

Academy of Sciences, September 27.-M. Léon Guignard in the chair.-A. Appell: A partial differential equation of the theory of hypergeometric functions.-F. E. Fournier: Concerning the apparent displacement of some stars in the total eclipse of the sun of May 29, I919.--M. Lugeon and N. Oulianoff : The geology of the Croix-de-Fer massif. The sedimentary zone separating the massif of Mont Blanc from that of the Aiguilles-Rouges has been usually considered as a simple sunclinal, but E. Paréjas has recently proved the existence of two synclinals. A study of the region between the Arve and the Trient has now shown that the structure is still more complex, a detailed description of which is given.C. Sauvageau: The indigenous marine algæ capable of furnishing gelose.- $\mathrm{V}$. Burson: $\Lambda$ solar prominence with great radial velocities. Photogranhs taken on September 8 showed a prominence visible on the photograph of the lower layer-a phenomenon of great rarity. This was followed up by a series of photographs, and certain parts were shown to have a radial velocity greater than $132 \mathrm{~km}$. per second.-H. Deslandres : Remarks on the preceding communication of V. Burson.-J. Welsch: Position of the springs on the concave bank of rivers in permeable limestone strata.- $\mathrm{R}$. Cerighelli: The घaseous exchanges of the root with the atmosphere. The respiration of plant-roots placed in a confined atmosphere takes place similarly to that occurring with other plant organs; the ratio of carbon dioxide 